\author{
Rea Lujić \\ University of Zadar, Croatia \\ Silvija Hanžić Deda \\ University of Zagreb, Croatia
}

\title{
PLURILINGUAL PRIMARY SCHOOL STUDENTS AND THEIR LANGUAGE USE
}

Summary. This case study examines the perspective of plurilingual primary school students on three aspects of their language use: code switching, positive language transfer and translation. In other words, the research question attempted to be answered in this paper is whether plurilingual primary school students use their communicative repertoires purposefully and strategically for their communication, acquisition, and learning of the languages. The research was conducted in a class of eighteen thirdgraders who attended an international primary school in Zagreb, with the average age of 9. Two questionnaires and a semi-structured interview were used to collect data about the students' language background, their language use, and their motives for engaging in code-switching, positive language transfer, and translation. In this research, the majority of the participants reported code-switching, the use of positive language transfer and translation. The findings also suggest the students are aware of the benefits that accompany plurilingualism, and that most of the participants possess significant metalinguistic awareness regardless of their young age. To sum up, this case study brings a valuable insight into the plurilingual world of primary school children and the development of their metalinguistic awareness.

Keywords: code-switching; positive language transfer; plurilingualism; plurilingual and pluricultural competence; translation.

\section{Introduction}

In the modern, super-diverse (Vertovec, 2007) world as we know it, one is witnessing a rapid flow of information, goods and people. Two consequences of such global movements stand out as significant for this topic: there is an increase in the number of individuals who use two or more languages on a daily basis, and there is a growing number of international schools around the world (Brummitt i Keeling, 2013) which provide appropriate education to the children of such individuals. The European Union has valued and fostered such linguistic and cultural pluralism for the last three decades. In order to both maintain and promote it, the term "plurilingual and pluricultural competence" has been coined and placed at the heart of language policies (e.g. Coste Moore \& Zarate, 
2009; Beacco et al., 2015). In the following sections, we will briefly present the theoretical background for our study: we will define the key terms such as plurilingualism, plurilingual competence, language transfer and codeswitching; we will describe our methodology, findings, and finally, we will offer our interpretations.

\section{Theoretical background}

According to the Council of Europe, the concept of plurilingualism implies that a language learning individual does not begin "at zero" with every new language. Instead, every new language extends the existing language knowledge of that individual. Furthermore, the language competences may vary from language to language, and the ideal of "near-nativeness" is irrelevant. The plurilingual and pluricultural competence refers to "the ability to use languages for the purposes of communication and to take part in intercultural interaction, where a person, viewed as a social agent, has proficiency of varying degrees in several languages and experience of several cultures". This is not seen as the superposition or juxtaposition of distinct competences, but, according to the Common European Framework of Reference for Languages (2001), "as the existence of a complex or even composite competence on which the user may draw one's ability to fulfil their communication needs appropriate for certain communication situation" (p. 168). The scientific legitimacy of the concept has been supported by a large body of research in the field of psycholinguistics (e.g. Grosjean, 1989; Cook, 1992; Herdina \& Jessner, 2002).

Königs (2000) identifies three types of plurilingualism (see also Neuner, 2004):

(a) retrospective plurilingualism, the case in which a bilingual learner brings their plurilingualism into the classroom, possessing substantial knowledge in L2 which is also the language of teaching;

(b) retrospective-prospective plurilingualism, in which a plurilingual learner advances in linguistic knowledge in comparison to their classmates, but none of the learner's languages are the teaching language, but that very language increases the learner's level of plurilingualism; 
(c) prospective plurilingualism, where a monolingual learner is emerged into a foreign language classroom, and their plurilingualism begins as the typical first foreign language learning situation.

Christ (2001) described a plurilingual individual as someone who is capable of crossing "the threshold" into the different "language houses" they possess, thus suggesting the existence of a "threshold level" necessary to cross, with the goal of adding a language to one's plurilingualism. From psycholinguistic point of view, plurilingual speech, typical for plurilingual individuals, can be defined as the speech production in which a plurilingual user activates the components of more languages at different levels. Code-switching and language transfer are two important characteristics of plurilingual speech. According to Romaine (1992), code-switching can be defined as the use of more than one language, variety or style by a speaker within an utterance or discourse, or between different interlocutors or situations (p. 110).

Plurilingual speakers use code-switching for multiple reasons: in situations when they do not know certain vocabulary (e.g. Gumperz, 1982; Malik, 1994; Cheng, 2003; Reyes, 2004; Arrifin \& Rafik Galea, 2012; Dahl, 2010; Amorim, 2012; Horasan, 2014), due to the non-existence or imprecision of words in one of the languages they use (e.g. Malik, 1994; Zentella, 1997; Cheng, 2003), when they feel tired or lazy (e.g. Grosjean, 1982; Malik, 1994), for the purpose of group affiliation (e.g. Malik, 1994; Eldridge, 1996; Holmes, 2000; Cheng, 2003; Ayeomoni Omoniyi, 2006), for expressing emotions (Holmes, 2000), and so on. The research has shown that monolingual students perceived code-switching as a positive and useful strategy which facilitated class communication (Pollard, 2002; Amorim, 2012; Horasan, 2014).

Another feature of plurilingual speech, language transfer, could be described as the process of implementing the elements of one language into another (Sharwood-Smith \& Kellerman, 1986, p. 1), which is the result of direct contact between two languages, and it primarily depends on language similarity (Kellerman, 1983), the level of language proficiency the speaker possesses (Kellerman, 1983; Odlin, 1989), and language recency (De Angelis, 2007). On the one hand, there is a large body of research on the negative effect of language transfer in the process of foreign language learning (e.g. Murphy, 2003; Cortés Calvo, 2005; Wang, 2009), and on the other hand, positive language transfer was less investigated (Odlin, 1989), especially 
among plurilingual speakers. The research on monolingual students' attitudes towards language transfer has revealed that students regarded it as a positive occurrence, but Prawat (1989) suggests that students should be made aware of its benefits in order to consider it positive, and Pea (1988) claims that students needed to be willing to take advantage of it.

Living in pluricultural communities, plurilingual speakers frequently find themselves in the communication situations that require translation from one language into another. In line with the natural translation model, plurilingual speakers develop their translation competence alongside their communicative competence (Harris, 1977 in Lörscher, 2012). Toury introduces the model of translation as transfer (1986, in Lörscher, 2012), according to which the plurilingual competence is important for translation, but mastering the transfer competence seems to be crucial for successful translation. However, the topic of translation from the perspective of plurilingual speakers still appears to be insufficiently explored.

Considering the fact that previous research of plurilingual speakers' speech did not include their personal perspectives, the aim of this study is to gain a thorough, qualitative insight into the language characteristics of plurilingual and pluricultural lower primary school students.

\section{Research methodology}

The objective of this paper is to achieve a better understanding of three aspects of language use among primary school plurilingual students, from their own perspective: code switching, positive language transfer and translation. In other words, the research question attempted to be answered in this paper is whether plurilingual primary school students use their communicative repertoires purposefully and strategically for the purpose of facilitating their communication, acquisition, and language learning.

This research was designed and conducted as a case study in a class of eighteen third-graders who attended an international primary school in Zagreb, with the average age of 9. The group consisted of eleven girls and seven boys ( $n=18$ ) who had been receiving their education in the English language, but they originated from all over the world. 
Three instruments were created for the purpose of this research: two questionnaires, My Language Biography, Me and My Languages, and a semistructured interview (see Appendices).

The My Language Biography questionnaire was based on the British Language Portfolio questions for primary school students (McLagan, 2006). The purpose of the data gathered by that questionnaire was twofold: a) to describe the group of participants, b) to interpret the answers collected in the other questionnaire. The second questionnaire, Me and My Languages, provided quantitative data necessary for achieving the objective of this research, and it was designed only for this purpose, based on the hypotheses which unfolded during the early research period. The questions of the semistructured interview were derived from the second questionnaire and provided useful qualitative data that facilitated the interpretation of that questionnaire.

Both questionnaires and interview questions were designed in the Croatian language and later translated into English (the language of communication in the school), using the method of double translation. In order to achieve validity and reliability, the instruments were piloted in a group of subjects who possessed similar developmental, educational and cultural characteristics.

After procuring the principal's and parents' informed consents in writing, the students were familiarized with the objective and the methods of this research. The completion of the two questionnaires was ordered as follows: first, My Language Biography, and then Me and My Languages. Lastly, the authors of this paper interviewed the students in collaboration with another language teacher who was known to the students.

\section{Participants}

The data collected by the means of the first questionnaire allowed a detailed insight into students' language biography. The acquisition level of English was practically equal among all students, and thus enabled them to follow their regular classes in the English language without major difficulties. However, for this research, two of the participants represented an exception regarding the English language in comparison to the rest of the group: one was a native speaker, and the other had been learning it intensively for eight months; 
i.e. she was only beginning to use it actively in classes. The rest of the students had been learning it for at least two years, that is, they had completed the previous two grades in the English language. In short, the common denominators to all students were: a good command of the English language, each spoke their mother tongue and between one and four other foreign languages. The group consisted of six students whose mother tongue was Croatian. Two of those students were born outside of Croatia and spent their early childhoods in foreign countries. There were nine students who acquired Croatian very well; they took Croatian classes together with the native speakers, but their mother tongues were: Azerbaijani, Russian, Chinese, Hungarian, Polish (x3), Slovenian, and Spanish. Three students learned Croatian as a second or third foreign language, and their mother tongues were Farsi, Slovak, and English.

When referring to abovementioned Königs' (2000) types of plurilingualism, the participants of this study belonged to the retrospectiveprospective type, with the exception of one student who belonged to the retrospective plurilingualism type.

The students' language biographies indicated that the majority of them were also pluricultural, since thirteen of them had lived in at least two foreign countries.

\section{Results and discussion}

The following section presents the quantitative data obtained from the questionnaire Me and My Languages, which was then completed and interpreted in combination with the information procured from the students' language biographies and a semi-structured interview.

\section{Code-switching}

This research has shown that two thirds of the participants, twelve out of eighteen, reported switching codes often while speaking, four of them reported doing that very often, one reported doing it rarely, and one participant reported 
not knowing whether he code-switched, or perhaps he was not aware of it (see Table 1).

Table 1.

Students' perception on code-switching

\begin{tabular}{|l|c|c|c|c|c|}
\hline $\begin{array}{l}\text { Frequency } \\
\text { of code- } \\
\text { switching }\end{array}$ & Very often & Often & $\begin{array}{c}\text { Do not } \\
\text { know }\end{array}$ & Rarely & Never \\
\cline { 2 - 6 } & 4 & 12 & 1 & 1 & - \\
\hline \multirow{2}{*}{ Codes } & L1-L2 & L2-L3 & L1-L3 & L3-L4 & L2-L4 \\
\cline { 2 - 6 } & 10 & 7 & 3 & 2 & 1 \\
\hline
\end{tabular}

With respect to codes, the languages were sequences from L1 to L4, according to the order of acquisition, which was obtained from the participants' language biographies. Observing horizontally, the bottom part of Table 1 shows that the majority of participants, ten of them, perceived that code-switching occurred between the two languages of which they had the best command: their mother tongues and English, the language of communication in school. Seven students perceived that code-switching occurred between their second and third languages, three of them between first and third, two participants reported code-switching between third and fourth, and one student reported code-switching between second and fourth language. However, more insightful conclusions on code-switching combinations could not have been reached due to the heterogeneity of the students' language biographies.

Nevertheless, the reasons of code-switching were revealed in the semistructured interview. The majority of students, eight of them, reported switching codes when they did not know a word or a phrase in the language spoken at a particular moment, six reported code-switching when having difficulty remembering otherwise familiar words or phrases, three students code-switched to include others in communication, two believed it was an easy option to start communication. Only one student reported fatigue as the reason for code-switching.

Although these results are impossible to generalize, it is evident that they are in concordance with the existing research results. For example, bilingual language learners often reported the use of code-switching when they experienced not knowing the appropriate words, when they were tired, or when they affiliated to certain groups. 
Interestingly, the participants first referred to places (at home, or at school) when asked When do you code-switch?, and subsequently, they explained their reasons and contexts.

\section{Positive language transfer}

Language comparison, as one of the positive language transfer techniques, was reported to be employed by eleven students out of eighteen; five reported using it very often, and two students reported not knowing whether they used it or not, which could be interpreted as their unawareness of the strategy at hand (Table 2).

Table 2.

Positive language transfer

\begin{tabular}{|l|c|c|c|c|c|c|c|}
\hline \multirow{2}{*}{$\begin{array}{l}\text { Positive } \\
\text { transfer } \\
\text { frequency }\end{array}$} & $\begin{array}{c}\text { Very } \\
\text { often }\end{array}$ & Often & $\begin{array}{c}\text { Do not } \\
\text { know }\end{array}$ & \multicolumn{2}{|c|}{ Rarely } & \multicolumn{3}{|c|}{ Never } \\
\cline { 2 - 8 } & 5 & 11 & 2 & - & \multicolumn{2}{|c|}{-} \\
\hline \multirow{2}{*}{ Languages } & L1-L2 & L1-L3 & L2-L3 & L1-L4 & L2-L4 & L3-L4 & L1-L1 \\
\cline { 2 - 8 } & 13 & 6 & 5 & 2 & 1 & 1 & 1 \\
\hline
\end{tabular}

As in Table 1, the languages were sequences from L1 to L4, according to the order of acquisition.

Observing horizontally, the bottom part of Table 2 shows the majority of students reported the comparison of the languages they were most familiar with, i.e., their mother tongues (L1) and English (L2). Six students reported comparing their first language (L1) to the language they had studied at school for the longest period of time (L3), and five students reported comparing English (L2) to the language they learned at school for the longest period of time (L3). Fewer students reported the comparison of other languages: two indicated comparing their first languages to the ones they started learning last or spoke very little, and finally, there was one report of each of the following combinations: the second language compared to the fourth, the third language 
to the fourth, and the first to the first. The latter is the case of a plurilingual student who is also a balanced bilingual. These results may imply that plurilingual speakers purposefully compared the languages, as a positive language transfer strategy, according to their levels of language mastery.

Furthermore, the reasons for which plurilingual students chose to compare languages, as one of the positive language transfer strategies, were mainly related to the similarity between languages: for ten students the similarity was in terms of vocabulary; for one it was in the pronunciation, and for another, it was in the orthography. These findings complement the conclusion from the previous section of this paper: apart from the level of language mastery, the students reported comparing their languages according to the interlingual similarities (i.e. language typology), which points to the fact that most of the participants possessed significant metalinguistic awareness, notwithstanding their young age. In addition to that, the ability to recognize similar words in various languages suggests high lexical and phonological awareness of the participants who reported frequent comparison of vocabulary.

Although it might be possible to implicitly conclude that knowing multiple languages simplifies the students' communication with others and enhances both foreign language acquisition and learning, it is significant that all eighteen participants offered the affirmative answer to the question whether knowing multiple languages facilitated the learning of new languages. Hence the implication that the participants of this case study were indeed plurilingual; they exploited their complex communicative repertoire purposefully and consciously.

\section{Translation}

Regarding translation as a language use, half of the participants stated that they translated words and phrases very often, five did it often, one rarely, one never, and two participants reported not knowing, and presumably, they might not have been aware of translating (Table 3). 
Table 3.

Translation frequency

\begin{tabular}{|l|c|c|c|c|c|}
\hline \multirow{2}{*}{$\begin{array}{l}\text { Translation } \\
\text { frequency }\end{array}$} & Very often & Often & $\begin{array}{c}\text { Do not } \\
\text { know }\end{array}$ & Rarely & Never \\
\cline { 2 - 6 } & $\mathbf{9}$ & $\mathbf{5}$ & $\mathbf{2}$ & $\mathbf{1}$ & $\mathbf{1}$ \\
\hline \multirow{2}{*}{ Languages } & L1-L2 & L1-L3 & L2-L3 & - & - \\
\cline { 2 - 7 } & 7 & 3 & 1 & - & - \\
\hline \multirow{2}{*}{ Reason } & communication & teaching & - & - & - \\
\cline { 2 - 7 } & 17 & 1 & - & - & - \\
\hline
\end{tabular}

As for the language combinations, it was somewhat expected that the participants of this case study predominantly would report translating from their first language (L1) to English (L2). That could be explained by the significance of the English language in the school environment. Furthermore, three students reported translating from L1 to the highest level foreign language (L3), and one from English (L2) to the highest level foreign language (L3). Those combinations represent the students' personal needs for communication at certain moments.

As Table 3 shows, almost all participants (17) reported that they translated for communication purposes and thus took the role of mediators between their family members or friends and the environment when a language barrier occurred. However, one participant said he translated "for his mother when she wants to learn new words in English", which introduces the role of a teacher that the student took when he believed was necessary.

Furthermore, it was valuable to hear five participants declaring they translated in their heads, in order to improve the comprehension and communication for themselves, in their second, third, or fourth language.

\section{Conclusion}

This case study provided a valuable insight into some of the language behaviour characteristics of plurilingual primary school students, and the three 
aspects of their plurilingual language use. The results show that the majority of plurilingual students reported the use of code-switching, positive language transfer, and translation. Furthermore, knowing multiple languages seemed to empower the students to communicate, acquire and learn new languages easier.

Firstly, the majority of participants reported code switching between the languages of which they had the best command, i.e. their first language and the English language when they were unable to produce the correct word in either of the two languages. Due to the participants' own initiative in specifying "forgotten words or phrases" as one of the reasons for code switching, future research should distinguish between forgetting the words and phrases, which were familiar at some point of life, and simple not knowing the words or phrases. The existing research results have not reported such distinction.

Secondly, the results of this case study also indicated that all participants believed that knowing multiple languages facilitated communication and foreign language learning. Moreover, all students reported comparing the languages strategically; those were most often the best known languages and similar languages, which is in line with previous research results. As the results of this study indicated, the participants were highly aware of both possibilities and effects of the positive language transfer. In addition, they actively used their complex communicative repertoires, which made them plurilingual according to the definitions in the EU documents.

Thirdly, the majority of the students found themselves in the role of mediators between the individuals who spoke their first language and the ones who spoke English. The purpose of such mediation was to enable the communication between others. For this reason, they consciously chose the translation strategy.

We are aware of the limitations of this study, primarily due to the small number of participants, and therefore, the results cannot be generalized. However, this research possesses multiple values which are derived from qualitative insight into plurilingualism. Apart from introducing the subject of (once known and then) forgotten words (and phrases) as a new function of code-switching, this study reveals that the plurilingual primary school students were well aware of the features of plurilingualism, and they were able to discuss 
them rationally, regardless of their origins and their characteristics of language biography.

Finally, the presented results point to possible topics of future research: whether the demonstrated level of metalinguistic awareness is a natural competence of plurilingual students or a positive effect of teaching adapted to a multilingual environment.

\section{References}

Amorim, R. (2012). Code switching in student-student interaction; functions and reasons. Revista de Estudos Linguisicos da Univerdada do Porto, 7, 177-195.

Arrifin, K., \& Rafik-Galea, S. (2012). Code Switching as a Communication Device in Conversation. Language \& Society Newsletter, 5. Retrieved from http www.crisaps.org/newsletter/summer 2009/Ariffin.doc.

Ayeomoni Omoniyi, M. (2006). Language Use in a Yoruba-Speech Community. Nebula, 161-172.

Beacco, J.C., Byram, M., Cavalli, M., Coste, D., Cuenat, M. E., Goullier, F., \& Panthier, J. (2015). Guide pour le développement et la mise en œuvre de curriculums pour une éducation plurilingue et interculturelle. Conseil de I'Europe: Strasbourg.

Brummitt, N., \& Keeling, A. (2013). Charting the Growth of International Schools. In R. Pearce (Ed.), International Education and Schools: Moving Beyond the first 40 Years (pp. 25-36). London: Bloomsbury.

Cheng, K. K. J. (2003). Code switching for a purpose: Focus on pre-school Malaysian children. Multilingua, 22, 59-77.

Christ, H. (2001). Wie das Postulat der Erziehung zur Mehrsprachigkeit den Fremdsprachenunterricht insgesamt verändert. Fachverband Moderne Fremdsprachen, Landesverband Niedersachsen, Mitteilungsblatt, 2, 29.

Cook, V. (1992). Evidence for Multicompetence. Language learning: A Journal of Research in Language Studies, 42(4), 557-591.

Cortés Calvo, N. (2005). Negative language transfer when learning Spanish as a foreign language. Interlingüística, 16(1), 237-248. 
Coste, D., Moore, D., \& Zarate, G. (2009). Plurilingual and pluricultural competence. Council of Europe: Strasbourg.

Council of Europe (2001). Common European Framework of Reference for Languages: Learning, Teaching, Assessment. Council of Europe: Strasbourg.

Dahl, K. (2010). Audience design and code switching in Bayside, Texas. Retrieved from http://repositories.lib.utexas.edu/handle/2152/ETDUT-2009-12-638.

De Angelis, G. (2007). Third or additional language acquisition. Clevedon: Multilingual Matters.

Eldridge, J. (1996). Code-switching in a Turkish secondary school. ELT Journal, $50(4), 303-331$.

Grosjean, F. (1982). Life with Two Languages: An Introduction to Bilingualism. Cambridge: Harvard University Press.

Grosjean, F. (1989). Neurolinguists, beware! The bilingual is not two monolinguals in one person. Brain Lang, 36(1), 3-15.

Gumperz, J. (1982). Discourse Strategies. Cambridge: Cambridge University Press.

Herdina, P., \& Jessner, U. (2002). A Dynamic Model of Multilingualism: Perspectives of Change in Psycholinguistics. Clevedon: Multilingual Matters.

Holmes, J. (2000). An Introduction to Sociolinguistics ( $2^{\text {nd }}$ ed.). Wellington: Longman.

Horasan, S. (2014). Code-switching in EFL classrooms and the perceptions of students and teachers. Journal of Language and Linguistic Studies, $10(1), 31-45$.

Kellerman, E. (1983). Now you see it, now you don't. In S. Gass, \& L. Selinker (Eds.), Language transfer in language learning (pp. 112-134). Rowley, MA: Newbury House.

Königs, F. G. (2000). Mehrsprachigkeit statt Sprachenlosigkeit. X. Lateinamerikanischer Germanistenkongress. Caracas, 1-17.

Lörscher, W. (2012). Bilingualism and Translation Competence. SYNAPS. A Journal of Professional Communication. Retrieved from https://brage.bibsys.no/xmlui/bitstream/handle/11250/2393971/ Lorscher_27.pdf?sequence $=1$. 
Malik, L. (1994). Socio-linguistics: A study of code-switching. New Delhi: Anmol Publications.

McLagan, P. (Ed.) (2006). My languages portfolio. European Language Portfolio - Junior version: Revised edition. London: CILT.

Murphy, S. (2003). Second Language Transfer During Third Language Acquisition. Working Papers in TESOL \& Applied Linguistics, 3(1). Retrieved from http://journals.tc-library.org/index.php/ tesol/article/view/23.

Neuner, G. (2004). The Concept of plurilingualism and tertiary language didactics. In B. Hufeisen \& G. Neuner (Eds.), The Plurilingualism Project: Tertiary Language Learning - German after English. Strasbourg: Council of Europe Publishing.

Odlin, T. (1989). Language transfer: cross-linguistic influence in language learning. Cambridge: Cambridge University Press.

Pea, R. D. (1988). Putting knowledge to use. In R. Nickerson \& P. Zodhiates (Eds.), Technology in education: Looking toward 2020. Hillsdale, N.J.: Lawrence Erlbaum Associates.

Pollard, S. (2002). The Benefit of Code Switching within a Bilingual Education Program. Honors Project. Retrieved from http://digitalcommons.iwu.edu/hispstu_honproj/2.

Prawat, R. S. (1989). Promoting access to knowledge, strategy, and disposition in students: A research synthesis. Review of Educational Research, 59, $1-41$.

Reyes, I. (2004). Functions of Code switching in Schoolchildren's Conversations. Bilingual Research Journal, 28(1), 77-98.

Romaine, S. (1992). Bilingualism. Blackwell Publishers: Cambridge.

Sharwood Smith, M., \& Kellerman, E. (1986). Crosslinguistic Influence in Second Language Acquisition. New York: Pergamon Press.

Vertovec, S. (2007). Super-diversity and its implications. Ethnic and Racial Studies, 30(6), 1024-1054.

Wang, X. (2009). Exploring the Negative Transfer on English Learning. Asian Social Science, 5(7), 137-143.

Zentella, A. C. (1997). Growing Up Bilingual: Puerto Rican Children in New York. Oxford: Blackwell. 


\section{Appendixes}

Appendix 1.

\section{MY LANGUAGE BIOGRAPHY}

\begin{tabular}{l} 
My name: \\
\hline I was born on: \\
\hline So far, I have lived in:
\end{tabular}

Languages I know, I learn or I have learned

\begin{tabular}{|l|l|l|l|}
\hline Language & $\begin{array}{l}\text { How long have I been learning / did } \\
\text { Ilearn this language? }\end{array}$ & $\begin{array}{l}\text { Where do / did I learn this } \\
\text { language? } \\
\text { (At home, at school...) }\end{array}$ & I speak this language with .... \\
\hline & & & \\
\hline & & & \\
\hline & & & \\
\hline
\end{tabular}

Date:

Appendix 2.

\section{ME AND MY LANGUAGES}

Read the statements below. Be honest, and for each statement, circle the symbol that best describes your answer. There are no correct or incorrect answers.

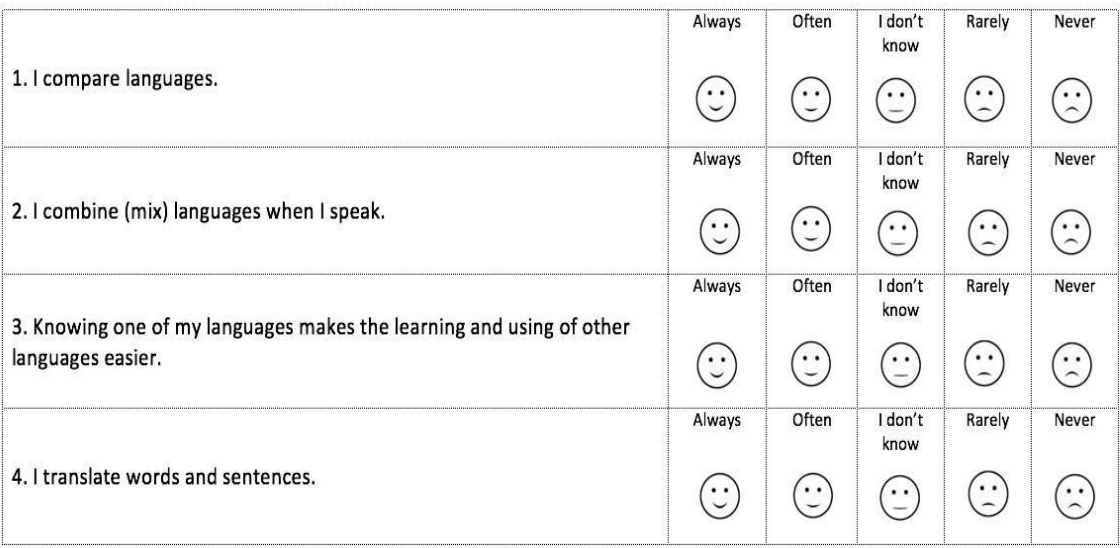

My name is: 
Appendix 3.

\section{Interview questions}

1. Which languages do you compare?

2. Which languages do you mix when you speak? When? Why?

3. Which one of your languages helps you learn and use other language(s)?

Give an example.

4. Who do you translate for? Why?

\section{Rea Lujić}

Zadaro universitetas, Kroatija; rlujic@unizd.hr

\section{Silvija Hanžić Deda}

Zagrebo universitetas, Kroatija; silvija.hanzic@gmail.com

\section{DAUGIAKALBIAI PRADINĖS MOKYKLOS MOKINIAI IR JU KALBOS VARTOJIMAS}

Santrauka. Šiame tyrime nagrinèjama daugiakalbiu pradinès mokyklos mokiniu perspektyva trimis ju kalbos vartojimo aspektais: kodu kaita, teigiamos kalbos perdavimu ir vertimu. Kitaip tariant, tyrime yra bandoma atsakyti i klausima, ar daugiakalbiai pradinès mokyklos mokiniai tikslingai ir strategiškai naudoja savo komunikacinius gebejimus kalbos komunikaciniams, isisavinimo ir mokymosi tikslams. Tyrime dalyvavo aštuoniolika trečios klasės mokiniu, kurie lankè tarptautinę pradinę mokykla Zagrebe, o ju vidutinis amžius buvo 9 metai. Duomenys apie mokiniu kalbos žinias, jos vartojima ir motyvus, skatinančius isitraukti i kodu kaita (teigiamos kalbos perdavima ir vertima), buvo surinkti naudojant du klausimynus ir pusiau struktūrizuota interviu. Šiame tyrime dauguma apklaustuju teigé naudojantys kodu kaita. Rezultatai taip pat atskleidè, kad mokiniai suvokia daugiakalbystès teikiamą nauda, ir nepaisant jauno amžiaus, dauguma apklaustuju turi reikšminga metalingvistini sąmoninguma. Šis tyrimas suteikia reikšmingos informacijos apie pradinès mokyklos mokiniu daugiakalbystę ir ju metalingvistinio sąmoningumo vystymą.

Pagrindinès sąvokos: kodu kaita; teigiamos kalbos perdavimas; daugiakalbystè; daugiakalbè ir daugiakultūrè kompetencija; vertimas. 